\title{
Connection between Heat Shock Proteins 60/65 and Diabetic Vascular Complications
}

\author{
Maciej Rabczyński ${ }^{1}$, Żanna Fiodorenko-Dumas ${ }^{2}$, Rajmund Adamiec ${ }^{1}$ and Małgorzata Paprocka-Borowicz ${ }^{2}$ \\ ${ }^{1}$ Department of Angiology, Hypertension and Diabetology, Wroclaw Medical University, Poland \\ ${ }^{2}$ Department of Physiotherapy, Wroclaw Medical University, Poland
}

\begin{abstract}
Introduction: Diabetes mellitus, as a metabolic disease, is closely associated with the development of atherosclerosis lesions. The share of heat shock proteins and antibodies in the HSP $-60 / 65$ atherogenesis in patients with type 2 diabetes is still an area subject to numerous studies.

Material and methods: The study was conducted in the group of 46 patients with type 2 diabetes mellitus with macrovascular complications and 62 patients with atherosclerosis. The control group was comprised of a cohort of healthy volunteers in the corresponding age. Tissue material acquired during the planned endarterectomy from the internal carotid artery was used to measure the serum levels of anti HSP 60/65, the plasma levels of vWF, and to perform the immunohistochemistry study.

Results: There was a higher concentration of anti HSP-60/65 in the group of patients with type 2 diabetes mellitus with macrovascular complications and patients with atherosclerosis without the endocrinopathies than in the control group $(55.67 \pm 65.43$ vs. $26.09 \pm 13.85,82.98 \pm 26.09$ vs. $111.18 \pm 13.85)$. Immunohistochemical method allowed observing a strong correlation between the concentration of antibodies to HSP60/65 in the blood serum and the protein expression of HSP $60 / 65$ in the carotid arterial wall. The concentration of antibodies to HSP $60 / 65$ was associated with the increase in the concentration of von Willebrand factor - marker of endothelial dysfunction $(R=0.388, p<0.01)$.

Conclusions: The research indicated an additional connection between the serum level of antibodies to HSP $60 / 65$ and of VWF, in patients with type 2 diabetic mellitus with macrovascular complications, suggesting their influence on endothelial cell damage in the course of diabetic vascular complications.
\end{abstract}

Keywords: Diabetes; Protein expression; Endothelium

\section{Introduction}

The diabetes morbidity rate is increasing at an alarming rate worldwide. This phenomenon can be noticed particularly in the developing countries and is related to the diagnosis of the disease among the groups of patients in increasingly younger age. It is estimated that up to $40-50 \%$ of the cases remain undiagnosed [1]. Diabetes mellitus, as a metabolic disease is closely associated with the development of atherosclerosis. The frequently concomitant classical risk factors connected with increased risk of cardiovascular diseases in patients with type 2 diabetes are: obesity, lipid disorders with hypertriglyceridemia, high LDL cholesterol, low HDL cholesterol level, atherogenic dysplipidemia, hypertension, and hyperinsulinemia and insulin resistance. Diabetic vascular complications, both microvascular and macrovascular, are associated with noticeable deterioration in the quality of life and are a major cause of most hospitalization cases, as well as of severe disability and of mortality among diabetic patients [2]. Accelerated development of atherosclerosis in diabetes is the major reason of medium and large blood vessel disease, termed angiopathy.

Heat shock proteins (HSP) belong to homogenous group of about 24 proteins with highly conserved amino acid sequence. HSP constitute a phylogenetically old cellular system that allows organisms to adapt to the impact of unfavorable factors [3,4]. In the basic conditions, they form $5-10 \%$ of the cellular protein; control the processes of replication, transcription, translation, synthesis and transport of the proteins crossing intracellular membranes. After the activation of the potentially harmful factor, intracellular pool of heat shock proteins is doubled, or even tripled, preventing cell spatial conformation changes of proteins, and thus the loss of their functions. Heat shock proteins are also referred to as chaperone molecule, as they prevent the formation of incorrect connections between molecules of different protein, and also are able to partially restore the spatial structure of the denatured protein.

Many research teams focus on the role of HSP 60,70 in the autoimmunity-based disease process, and particularly on the involvement of these proteins in the pathogenesis of rheumatoid arthritis, Kawasaki disease, systemic lupus, multiple sclerosis, Behçet's disease, psoriasis or Hashimoto's thyroiditis [5].

The connection of heat shock proteins with immune destruction of pancreatic islet $\beta$ cells in diabetes remains partially unexplained [6].

The highly conserved structure of these proteins results in the possibility of cross-reaction of these antibodies emerging from the immune response against bacterial antigens and the autogenously HSP of human cells undergoing stress factors. This phenomenon, known as antigenic mimicry, was suggested by the authors in 1990 [7]. Large number of studies has been conducted on the influence of

*Corresponding author: Żanna Fiodorenko-Dumas, Department of Physiotherapy, Wroclaw Medical University; 2 Grunwaldzka Street, 50-355 Wroclaw, Poland Tel: +48605955424; E-mail: z.fiodorenko@poczta.onet.pl

Received March 11, 2013; Accepted April 21, 2013; Published April 26, 2013

Citation: Rabczyński M, Fiodorenko-Dumas Ż, Adamiec R, Paprocka-Borowicz M (2013) Connection between Heat Shock Proteins 60/65 and Diabetic Vascular Complications. J Diabetes Metab S13: 001. doi:10.4172/2155-6156.S13-001

Copyright: @ 2013 Rabczyński M, et al. This is an open-access article distributed under the terms of the Creative Commons Attribution License, which permits unrestricted use, distribution, and reproduction in any medium, provided the original author and source are credited. 
the heat shock proteins HSP 60/65 on the pathogenetic processes of atherosclerosis and its potential complications.

The first evidence confirming the HSP involvement in atherosclerosis has been provided by an experiment conducted on an animal model, described by Xu et al. in 1992 [8]. The development of the atherosclerotic plaques was observed only in the animals that received the heat shock protein $65 \mathrm{kDa}$ (HSP - 65) of bacterial origin (M. tuberculosis) or the purified recombinant of the protein in the antigen preparation. The effect was independent of other antigenic components of the solution given by injection. Further evidence has been provided by the results of epidemiological studies conducted among the group of 867 residents of South Tyrol [9]. Antibody titers to HSP - 65 were compared with the atherosclerotic lesions in the carotid arteries, assessed by carotid duplex Doppler ultrasonography. Significantly higher antibody titers were noticed in patients with atherosclerosis [10]. Similar results regarding the concomitance of atherosclerotic lesions and the presence of antibodies serum anti HSP $60 / 65$ were obtained in the study of patients with chronic limb ischemia resulting from arteriosclerosis obliterans [11].

The most extensive research material that has been collected refers to the participation of antibodies to HSP 60/65 in the development of coronary artery atherosclerosis. In their study of 391 patients angiographically diagnosed in the direction of coronary heart disease, Zhu et al. [12] showed a statistically significantly higher incidence of HSP 60 antibodies in the serum of patients with diagnosed coronary artery disease [13]. Japanese researchers determined the relationship between unstable coronary artery disease and the antibody titer to HSP $60[14]$.

Patients with type 2 diabetes are particularly predisposed to the development of vascular complications. Participation of the HSP 60/65 in these patients has not yet been thoroughly specified. Therefore, an attempt to assess the role of heat shock proteins in the pathogenesis of macrovascular HSP60/65 diabetic has been made. It was decided to examine patients with type 2 diabetes complicated by peripheral macrovascular disease in the area; patients with chronic lower limb ischaemia; and patients with atherosclerotic narrowing of arteries supplying the brain scheduled for carotid endarterectomy because of its significant stenosis.

The aim of the study is: 1 to determine the participation of heat shock proteins in the development of diabetic macrovascular disease by measuring the concentration of anti-HSP $60 / 65$ antibody in the serum of patients with diabetes vascular complications. 2 . To carry out the imunohistochemical examination of the carotid artery specimens in order to demonstrate the connection between the presence of heat shock proteins in the cells of the vascular wall and the antibody concentration of anti-HSP 60/65 in blood serum.

\section{Research Material}

The study was approved by the Commission of Bioethics at Wroclaw Medical University. All persons participating in the study were informed of the purpose and gave their written consent.

The study included patients with type 2 diabetes mellitus with macrovascular complications and patients with atherosclerosis, treated at the Department of Angiology, Hypertension and Diabetology, Wroclaw Medical University. The participants were divided into two main groups:

\section{Group I}

Experimental $(\mathrm{n}=46)$ - patients with type 2 diabetes and macrovascular complications ( 14 women and 32 men), aged from 48 to 63 years (mean age $55.32 \pm 3.24$ years), including 30 people (Group A) patients with type 2 diabetes with impaired peripheral circulation, 10 women and 20 men, aged from 48 to 60 years (mean age $54.73 \pm$ 3.35 years) with symptoms of intermittent claudication and 16 patients (Group B) impaired carotid circulation, 4 women and 12 men, aged from 51 to 63 years (mean age $56.43 \pm 2.80$ years) qualified for carotid endarterectomy. Patients with narrowing of the internal carotid artery $>70 \%$ (color coded Doppler flow) and clinical signs of underlying CNS ischemia - a history of stroke, episodes of Transient Ischemic Attack (TIA), sudden loss of vision were eligible for this group.

\section{Group II}

Comparison ( $\mathrm{n}=62)$ patients ( 13 women and 49 men), without diabetes mellitus, with atherosclerotic stenosis of the supraaortic and peripheral vascular vessels, aged from 44 to 64 years (mean 54 \pm 3.86 years). In the 37 patients (Group C) with impaired peripheral circulation, 5 women and 32 men, aged from 44 to 58 years (mean age $53.29 \pm 3.14$ years) with symptomatic lower limb perfusion deficit of the same advancement as group A and 25 patients (Group D) with reduced carotid cardiovascular, 8 women and $17 \mathrm{men}$, aged from 46 to 64 years (mean age $55.44 \pm 4.50$ years) scheduled for carotid endarterectomy with carotid artery narrowing internal $>70 \%$ (color coded Doppler flow) and with concomitant clinical signs of CNS ischemia - a history of stroke, episodes of Transient Ischemic Attack (TIA), sudden loss of vision.

Patients who had the symptoms of infection or inflammation within the past 3 months or who suffered from acute coronary syndrome within the last 6 months were excluded from the participation in the study. Patients who took non-steroidal anti-inflammatory drugs (with the exception of aspirin at a dose to $325 \mathrm{mg} /$ day) and those diagnosed with cancer, liver disease or another serious associated illness were also excluded.

\section{The control group}

Control group $(\mathrm{n}=18)$ consisted of healthy volunteers ( 9 women and 9 men) aged from 40 to 59 years (mean age $50.38 \pm 5.29$ years).

\section{Methods}

Blood pressure was obtained as the average of 3 consecutive measurements at five-minute intervals, measured in patients in the sitting position. As recommended by the JNC VII report, hypertension was diagnosed in case of values above $140 / 90 \mathrm{mmHg}$ or chronic antihypertensive medication.

Venous blood sample was collected from each participant's antecubital vein in the morning. 16-parameter hematology analyzer ABX MIKROS OT was used to conduct the morphology of the peripheral blood. Lipid concentration was assessed by the enzymatic methods using Analco Test (Analco Medical Trade;, Warszawa, Poland).

Creatinine, urea, uric acid, fibrinogen was measured using the Behring Coagulation Timer Analyzer. In order to determine the antibody concentration of anti-HSP $60 / 65$ in the serum, blood was collected in the morning from the antecubital vein. During the 30 minutes of blood collection, the blood was centrifuged for $10 \mathrm{~min}$, 
speed $3000 \mathrm{rpm}$. The resulting serum was stored at a temperature below $-40^{\circ} \mathrm{C}$ to the time of the marking.

The assay was made with the Anti-Human Hsp60 (total) ELISA kit (catalog number EKS-650) from Stressgen. The values of antibody concentration are expressed in $\mathrm{ng} / \mathrm{ml}$.

In order to assay the concentration of von Willebrand factor (vWF) in plasma, blood was collected in the morning from the antecubital vein into tubes containing $3.2 \%$ sodium citrate solution and during the 30 minutes of collection the blood was centrifuged for $15 \mathrm{~min} 5000 /$ min at speed. The resulting plasma was stored at a temperature below $-40^{\circ} \mathrm{C}$ to the time of the marking.

Assay was performed with ELISA using Asserchrom VWF: Ag kits (Catalog No. 00942 REF) Diagnostica Stago. The concentration values are expressed in $\%$ of the standard.

Immunohistochemical examinations of carotid specimens to HSP $60 / 65$ detect were carried out in the Department of Pathology, Wroclaw Medical University. The study used tissue material obtained at the time of the internal carotid artery endarterectomy and fixed in 10\% buffered formalin and embedded in paraffin blocks.

The paraffin blocks containing the fixed tissue were prepared using a microtome sections of a thickness of 4 microns, which were then placed on silanized slides (DAKO No. S 3003), and pieces were deparafined in xylene and converted by a series of decreasing concentrations of alcohol to water. Endogenous peroxidase was blocked with $3 \% \mathrm{H}_{2} \mathrm{O}_{2}$ solution for 10 minutes. From each block, preparations were made to assess HSP 60/65. Furthermore, immunohistochemical preparations for the control group containing breast cancer tissue were prepared in the same way.

In order to detect analyzed protein, a three-stage immunohistochemical $\mathrm{ABC}$ method was used. This method involves the application of biotin-labeled secondary antibody followed by the addition of avidin-biotin-peroxidase complex. Primary antibody was used to study the mouse monoclonal antibody directed against HSP60 ((H (IHC, WB) M (IHC, WB) R (IHC, WB) antibodies, Purified Mouse Monoclonal IgG, clone 264233, catalog number MAB 1800, R \& D Systems).

Immunohistochemistry examination was performed according to the protocol used in laboratory histopathology. Before the incubation with the primary antibody, the antigens tissues previously fixed in formalin were retrieved in Target Retrival Solution (Dako ${ }^{\circ}$ No. S 1700) by heating in a water bath at $96^{\circ} \mathrm{C}$ for 30 minutes.

Tissue sections were incubated with diluted (1:200) primary H M R antibodies to HSP 60 by 60 minutes at room temperature. The secondary biotinylated antibody ( $\mathrm{LSAB}^{\circ}+\mathrm{Kit}$, Dako) was then applied for $15 \mathrm{~min}$. It was preceded by rinsing in TBS. After washing in TBS, sections were incubated with streptavidin peroxidase complex (LSAB + Kit, DAKO $\mathrm{K}$ 0675) for 15 minutes. Immunohistochemical examination was developed in 3, 3'-diaminobendine tetrahydrochloride (DAB +, DAKO Liquid $\mathrm{K}$ 3486). Then the sections were washed in running water and dehydrated in an alcohol series, cleared in xylene and mounted in Canadian balsam.

Evaluation of protein expression was examined in the polarizing microscope Olympus BX41 with video channel, ocular $\times 10$, objective $\times 20$, using microscopic image analysis using the software DOCU Analysis (version 3.2 for Windows 95/98/NT, the company Soft Imaging $\mathrm{GmbH}$, License No: 100 7557).
Expression of the examined proteins was evaluated by semi quantitative method. Microscopic picture (magnification $\times 200$ ) of preparation was sent to Analysis doc software and then the randomly selected fields for the presence of the protein were analyzed.

For the semi-quantitative assessment of the degree of HSP60 protein expression in endothelial cells, an original scale was used:

0 - no expression

$+\quad$ - poor response, observed in a few cells

$++\quad$ - moderate reaction, observed in quite a number of cells, but in less than half of the visible cells

+++ - strong reaction, observed in more than half of all cells

++++- a very strong reaction, observed in all cells

The level of statistical significance for all tests was set at $\mathrm{p}<0.05$. Due to the nonparametric distribution of traits analyzed in the groups, the Mann-Whitney $U$ test was used. The presence of dependencies between features was verified by the Spearman rank correlation test. The strength of correlation is expressed in the form of the correlation coefficient R. A positive value indicates a positive relationship and a negative - the reversed relationship. All calculations were performed using Statistica-7 software package (StatSoft Inc., Tulsa, USA).

\section{Results}

Selected clinical parameters characterizing the groups in terms of sex, age, smoking status, comorbidities, etc. were summarized in table 1 . The analysis of laboratory parameters was illustrated in table 2 . Groups of medicines used by patients participating in the study were presented in table 3 . The results in the tables are expressed as means \pm standard deviation (NS - statistically not significant).

The group of diabetic patients (Group I) showed higher levels of triglycerides and lower HDL cholesterol values than the control group, but without statistical significance compared to the comparative group (Group II). Higher LDL cholesterol and creatinine level was observed in patients with obliterative atheromatosis than in the control group, within the limits of the reference standard. Patients with symptoms of lower limb ischemia with (Group A) or without diabetes (Group C) were characterized by higher concentrations of uric acid - within the limits of the reference standard. Other parameters, such as ESR, WBC, fibrinogen or urea, did not differ significantly between the diabetic group and the control group.

Patients with diabetic macroangiopathy in both analyzed peripheral blood areas (Group I) had higher levels of anti-HSP 60/65 in the serum then healthy volunteers (the control group) $(55.67 \pm 65.43$ vs. 26.09 $\pm 13.85, \mathrm{p}<0.05)$. Similar relationships were observed in patients with advanced atherosclerosis without disorders of carbohydrate

\begin{tabular}{|c|c|c|c|c|c|}
\hline \multirow{2}{*}{} & \multicolumn{2}{|c|}{$\begin{array}{c}\text { Diabetes mellitus type } \\
\text { 2 group I }\end{array}$} & \multicolumn{2}{|c|}{$\begin{array}{c}\text { Atherosclerosis } \\
\text { group II }\end{array}$} & \multirow{2}{*}{ control group } \\
\cline { 2 - 6 } & $\mathbf{A}$ & $\mathbf{B}$ & $\mathbf{C}$ & $\mathbf{D}$ & \\
\hline $\mathbf{N}$ & $\mathbf{3 0}$ & $\mathbf{1 6}$ & $\mathbf{3 7}$ & $\mathbf{2 5}$ & $\mathbf{1 8}$ \\
\hline women/ man & $10 / 20$ & $4 / 12$ & $5 / 32$ & $8 / 17$ & $9 / 9$ \\
\hline age [years] & $54.7 \pm 3.6$ & $56.4 \pm 2.8$ & $53.3 \pm 3.1$ & $55.4 \pm 4.5$ & $50.4 \pm 5.3$ \\
\hline smoking [\%] & $96 \%$ & $94 \%$ & $100 \%$ & $100 \%$ & $58 \%$ \\
\hline hypertension [\%] & $90 \%$ & $75 \%$ & $57 \%$ & $60 \%$ & - \\
\hline BMl [kg/m²] & $28.8 \pm 3.9$ & $26.9 \pm 3.6$ & $25.5 \pm 3.5$ & $25.2 \pm 3.9$ & $26.9 \pm 4.8$ \\
\hline
\end{tabular}

Results are expressed as mean \pm standard deviation.

Table 1: Selected clinical parameters of the analyzed groups of patients. 
Citation: Rabczyński M, Fiodorenko-Dumas Ż, Adamiec R, Paprocka-Borowicz M (2013) Connection between Heat Shock Proteins 60/65 and Diabetic Vascular Complications. J Diabetes Metab S13: 001. doi:10.4172/2155-6156.S13-001

Page 4 of 7

\begin{tabular}{|c|c|c|c|c|c|c|}
\hline & \multicolumn{2}{|c|}{ Diabetes mellitus type 2 group I } & \multicolumn{2}{|c|}{ Atherosclerosis group II } & \multirow{2}{*}{ control group } & \multirow{2}{*}{ significance } \\
\hline & A & B & C & D & & \\
\hline Creatinine $[\mathrm{mg} / \mathrm{dl}]$ & $1.1 \pm 0.3$ & $1.0 \pm 0.2$ & $1.1 \pm 0.2$ & $1.2 \pm 0.4$ & $0.9 \pm 0.1$ & $\begin{array}{l}\text { A vs. C; NS } \\
\text { B vs. D; NS } \\
\text { A vs. contr.; } p<0.001 \\
\text { B vs. contr.; NS } \\
\text { C vs. contr.; } p<0.005 \\
\text { D vs. contr.; } p<0.05\end{array}$ \\
\hline uric acid [mg/dl] & $5.1 \pm 1.3$ & $4.2 \pm 1.0$ & $5.2 \pm 1.2$ & $4.5 \pm 1.2$ & $4.0 \pm 1.4$ & $\begin{array}{l}\text { A vs. C; NS } \\
\text { B vs. D; NS } \\
\text { A vs. contr.; } p<0.001 \\
\text { B vs. contr.; NS } \\
\text { C vs. contr.; p<0.01 } \\
\text { D vs. contr.; NS }\end{array}$ \\
\hline total cholesterol [mg/dl] & $217.4 \pm 49.0$ & $180.3 \pm 49.0$ & $229.4 \pm 43.3$ & $205.2 \pm 47.2$ & $189.4 \pm 25.4$ & $\begin{array}{l}\text { A vs. C; NS } \\
\text { B vs. D; NS } \\
\text { A vs. contr.; } p<0.05 \\
\text { B vs. contr.; NS } \\
\text { C vs. contr.; p<0.001 } \\
\text { D vs. contr.; NS }\end{array}$ \\
\hline LDL cholesterol [mg\%] & $118.8 \pm 43.5$ & $85.9 \pm 31.8$ & $148.1 \pm 43.8$ & $119.6 \pm 41.7$ & $102.8 \pm 25.3$ & $\begin{array}{l}\text { A vs. C; } p<0.01 \\
\text { B vs. D; } p<0.05 \\
\text { A vs. contr.; NS } \\
\text { B vs. contr.; NS } \\
\text { C vs. contr.; } p<0.001 \\
\text { D vs. contr.; NS }\end{array}$ \\
\hline $\mathrm{HDL}$ cholesterol [mg/dl] & $48.4 \pm 12.3$ & $46.1 \pm 11.7$ & $46.4 \pm 11.7$ & $54.2 \pm 17.2$ & $67.2 \pm 14.1$ & $\begin{array}{l}\text { A vs. C; NS } \\
\text { B vs. D; NS } \\
\text { A vs. contr.; } p<0.001 \\
\text { B vs. contr.; } p<0.001 \\
\text { C vs. contr.; } p<0.001 \\
\text { D vs. contr.; } p<0.01\end{array}$ \\
\hline triglycerides [mg/dl] & $293.1 \pm 235.5$ & $217.5 \pm 120.4$ & $173.1 \pm 74.1$ & $167.8 \pm 91.4$ & $97.2 \pm 39.3$ & $\begin{array}{l}\text { A vs. } C ; p<0.01 \\
\text { B vs. D; NS } \\
\text { A vs. contr.; } p<0.001 \\
\text { B vs. contr.; } p<0.001 \\
\text { C vs. contr.; } p<0.001 \\
\text { D vs. contr.; } p<0.01\end{array}$ \\
\hline
\end{tabular}

Results are expressed as mean \pm standard deviation. NS: Not Statistically Significant

Table 2: Selected laboratory parameters of the analyzed groups.

\begin{tabular}{|c|c|c|c|c|}
\hline \multirow[b]{2}{*}{ Medicines groups } & \multicolumn{2}{|c|}{ Diabetes mellitus type 2 group I } & \multicolumn{2}{|c|}{ Atherosclerosis group II } \\
\hline & $\begin{array}{c}A \\
(30)\end{array}$ & $\begin{array}{c}B \\
(16)\end{array}$ & $\underset{(37)}{C}$ & $\begin{array}{c}D \\
(25)\end{array}$ \\
\hline Acetylsalicylic acid & $28 / 30(93.3 \%)$ & $14 / 16(87.5 \%)$ & $36 / 37(97 \%)$ & $22 / 25(88 \%)$ \\
\hline Statins & $17 / 30(56.6 \%)$ & $10 / 16(62.5 \%)$ & $21 / 37(56.7 \%)$ & $18 / 25(72 \%)$ \\
\hline Fibrates & $4 / 30(13.3 \%)$ & $2 / 16(12.5 \%)$ & $3 / 37(8 \%)$ & $4 / 25(16 \%)$ \\
\hline Converting enzyme inhibitors & $18 / 30(60 \%)$ & $12 / 16(75 \%)$ & $23 / 37(62 \%)$ & $14 / 25(56 \%)$ \\
\hline Diuretics & $6 / 30(30 \%)$ & $1 / 16(6.25 \%)$ & $8 / 37(21 \%)$ & $5 / 25(20 \%)$ \\
\hline$\beta$ - blockers & $9 / 30(30 \%)$ & $5 / 16(31,2 \%)$ & $19 / 37(51 \%)$ & $10 / 25(40 \%)$ \\
\hline Calcium channel blockers & $2 / 30(6,66 \%)$ & 0 & $3 / 37(8 \%)$ & $1 / 25(4 \%)$ \\
\hline Insulin & $13 / 30(43,3 \%)$ & $8 / 16(50 \%)$ & - & - \\
\hline
\end{tabular}

Table 3: Groups of medicines used by the patients participating in the study.

metabolism (Group II) $(111.18 \pm 82.98$ vs. $26.09 \pm 13.85, \mathrm{p}<0.01)$ (Table 4).

The von Willebrand factor is the marker of vascular endothelial dysfunction in the course of an inflammatory response; Table 4 summarizes the concentration of vWF in particular groups.

Higher concentration of vWF was observed in patients with diabetic macroangiopathy in both peripheral blood analyzed areas (Group $\mathrm{A}+\mathrm{B})$ than in healthy volunteers from the control group (142.30 \pm 42.04 vs. $97.28 \pm 19.85, \mathrm{p}<0.05)$ [15]. In addition, the connection between the concentration of antibody to HSP $60 / 65$ and the serum levels of vWF $(\mathrm{R}=0.388, \mathrm{p}<0.01)$ was identified in patients with symptoms of vasoconstriction against macrovascular diabetic (Group I) (Table 5; Figure 1).
Tissue preserved in $10 \%$ buffered formalin and embedded in paraffin blocks were used for immunohistochemistry. Samples collected from 20 patients - 7 women and 13 men aged from 47 to 64 years (mean age $55.35 \pm 3.49$ years). There were 8 type 2 diabetic and 12 healthy patients in this group.

Expression of HSP 60/65 was evaluated by semi quantitative scale according to the authors' own method. In 19 preparations (95\% of cases), the presence of HSP 60/65 was observed. Only in one of the preparations the expression of HSP 60/65 was not detected. In 6 cases the expression of proteins was evaluated as poor, and observed in a few cells $(+)$, in another six as moderate response, noticed in quite a number of cells, but less than half of visible cells $(++)$. In 5 cases the expression was strong, visible in more than half of the cells $(+++)$, and 
Citation: Rabczyński M, Fiodorenko-Dumas Ż, Adamiec R, Paprocka-Borowicz M (2013) Connection between Heat Shock Proteins 60/65 and Diabetic Vascular Complications. J Diabetes Metab S13: 001. doi:10.4172/2155-6156.S13-001

Page 5 of 7

\begin{tabular}{|c|c|c|c|}
\hline & $\begin{array}{c}\text { Diabetes mellitus } \\
\text { type 2 group I }\end{array}$ & $\begin{array}{c}\text { Atherosclerosis } \\
\text { group II } \\
\text { (A+B) }\end{array}$ & $\begin{array}{c}\text { Control } \\
\text { group }\end{array}$ \\
\cline { 2 - 3 } $\begin{array}{c}\text { (C+D) } \\
\text { anti- HSP 60/65 } \\
{[\mathrm{ng} / \mathrm{ml}]}\end{array}$ & $55.67 \pm 65.43$ & $82.98 \pm 111.18$ & $26.09 \pm 13.85$ \\
\hline significance & $\begin{array}{c}\text { A+B vs. C+D; NS } \\
\text { A+B vs. contr; } p<0.05\end{array}$ & $\begin{array}{c}\text { C+D vs. contr; } \\
\text { p }<0.01\end{array}$ & \\
\hline
\end{tabular}

Results are expressed as mean \pm standard deviation. NS: Not Statistically Significant

Table 4: The concentration of anti-HSP 60/65 antibody in the serum of patients with diabetic macrovascular disease and of patients with atherosclerosis without disorders of carbohydrate metabolism.

\begin{tabular}{|l|l|l|l|}
\hline & \begin{tabular}{l} 
Diabetes mellitus \\
type 2 group I \\
\cline { 2 - 3 }
\end{tabular} & $\begin{array}{l}\text { Atherosclerosis } \\
\text { group II }\end{array}$ & Control group \\
\hline VWF [\%] & $142.30 \pm 42.04$ & (C+D) & $97.28 \pm 19.85$ \\
\hline significance & $\begin{array}{l}\text { A+B vs. C+D; NS } \\
\text { A+B vs. contr; } p<0.05\end{array}$ & C+D vs. contr; $p<0.001$ & \\
\hline
\end{tabular}

Results are expressed as mean \pm standard deviation. NS: Not Statistically Significant

Table 5: vWF concentration in the serum of patients with diabetic macroangiopathy and of patients with atherosclerosis without disorders of carbohydrate metabolism.

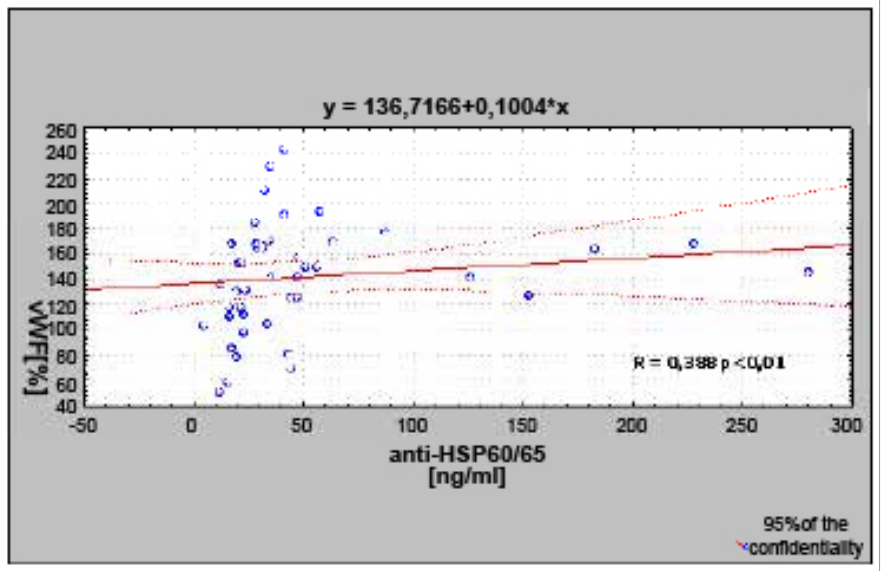

Figure 1: Dependence of the concentration of VWF on the concentration of antibody to HSP $60 / 65$ in the serum of patients with diabetic macrovascular disease (group A + B)

in four it was identified as very strong, visible in all cells $(++++)$. The results are summarized in table 6 .

Expression of HSP 60/65 was showed in carotid artery endothelial cells (Figure 2), and endothelial cells of the vasa vasorum (Figure 3). The presence of the protein in the medial was recognized mainly in macrophages (Figures 4 and 5).

The relationship between the concentration of the anti-HSP 60/65 in the serum and the expression of HSP proteins 60/65 assessed in the immunohistochemical study was observed in patients with symptomatic carotid artery stenosis with diabetic macroangiopathy (Group B), atherosclerosis (Group D), and together the two groups (Group $\mathrm{B}+\mathrm{D}$ ). Thus, the correlation in group $\mathrm{B}$, with $\mathrm{p}<0.005$ was $\mathrm{R}=0.786$; in group $\mathrm{D}, \mathrm{p}<0.05, \mathrm{R}=0.699$, and the two groups together $\mathrm{B}+\mathrm{D}, \mathrm{p}<0.005 \mathrm{R}=0.660 ; \mathrm{p}<0.005$ (Figure 6).

\section{Discussion}

Diabetes promotes atherogenesis in particular, but the role of heat shock proteins in the development of diabetic macrovascular disease has not been evaluated yet. Although patients with diabetes were also participating in the above research [16], the disease was considered only an additional strong risk factor for atherosclerosis.

Since it was found, during the experimental studies on an animal model, that intravascular administration of antigen mycobacterium mHSP 65 promoted the development of atherosclerotic changes of arteries [17], and Maron et al. [18] confirmed the role of HSP 60/65 in atherogenesis and suggested the possibility of the control of the progression of atherosclerosis through the induction of immune tolerance to these proteins, the search for potential, pro-atherosclerotic properties of heat shock proteins has been continued. One of the proposed mechanisms that are considered is the stimulation of an immune response by the protein to form the anti-HSP 60/65 antibodies.

\begin{tabular}{|c|c|c|c|c|c|}
\hline Expression & $\begin{array}{c}\text { No } \\
\text { expression } \\
\mathbf{( 0 )}\end{array}$ & Poor (+) & Moderate (++) & $\begin{array}{c}\text { Strong } \\
\mathbf{( + + + )}\end{array}$ & $\begin{array}{c}\text { Very strong } \\
\mathbf{( + + + + )}\end{array}$ \\
\hline $\mathrm{n}(20)$ & 1 & 6 & 6 & 5 & 2 \\
\hline
\end{tabular}

Table 6: Level of expression of protein HSP 60/65 in immunohistochemistry preparations.

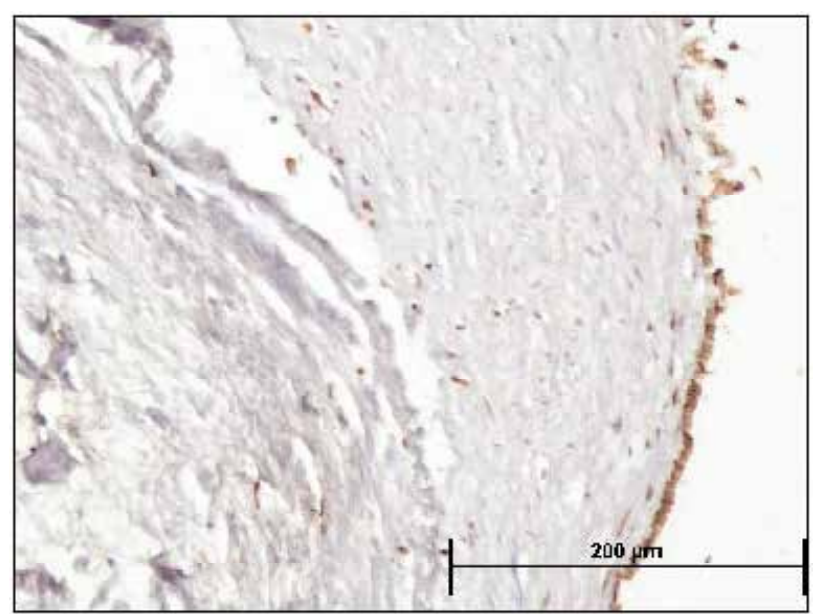

Figure 2: Expression of HSP $60 / 65$ in the endothelial cells of the carotid artery.

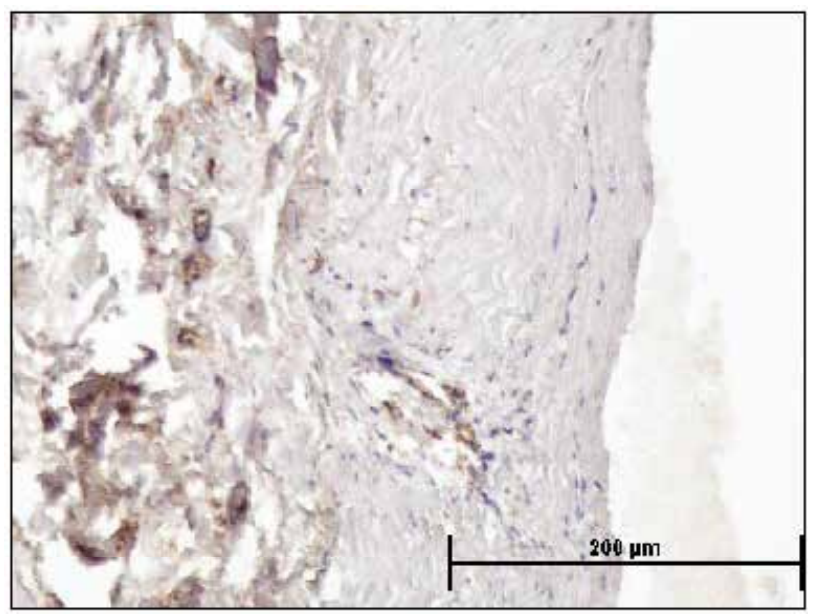

Figure 3: Expression of HSP 60/65 in endothelial vasa vasorum. 


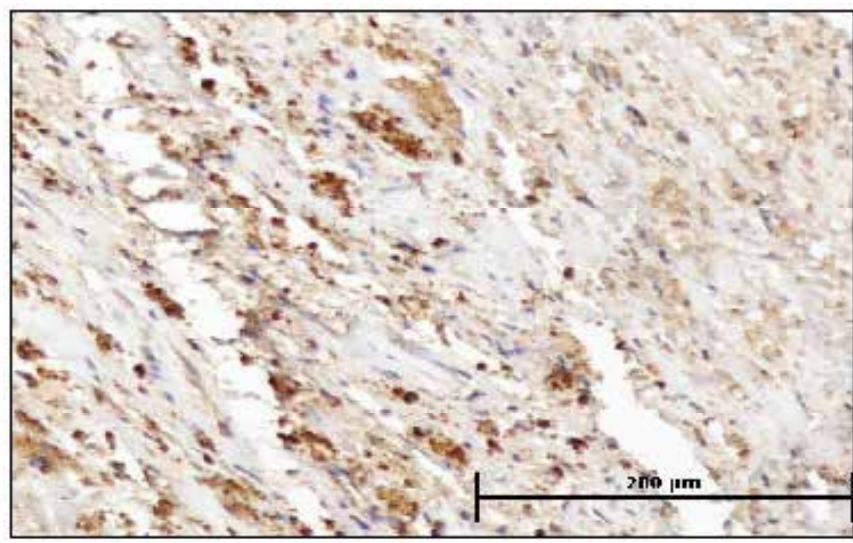

Figure 4: Expression of HSP 60/65 in macrophages of aortic media.

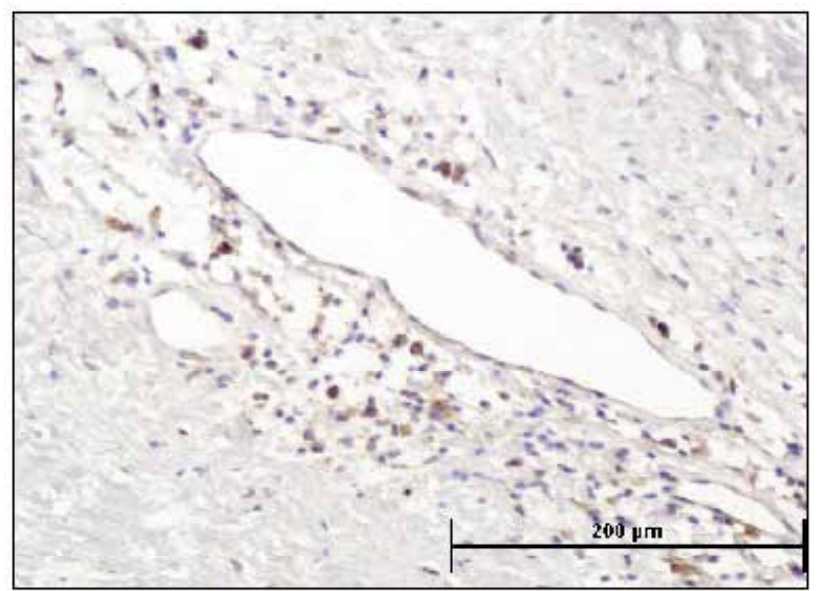

Figure 5: Expression of HSP 60/65 in macrophages of aortic media and endothelium vasa vasorum.

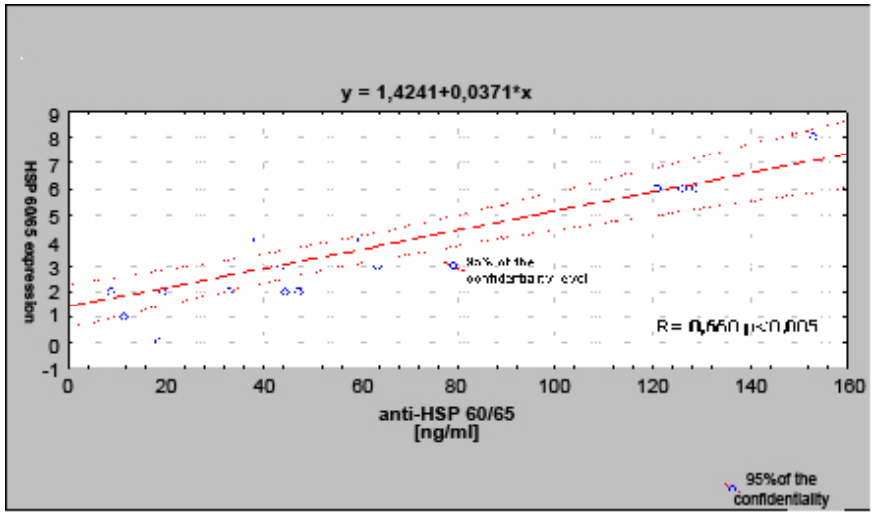

Figure 6: Dependence of protein HSP 60/65 expression in a sample of the carotid artery on the concentration of anti-HSP 60/65 (group B + D).

As a result of structural modification, stimulated by the oxidative stress or metabolic disorders [19], autologous heat shock protein could become immunogenic antigen and form complexes with other foreign antigens. Some authors believe that the intracellular protein may not be recognized by the immune system as its own when in the extracellular - sHSP (soluble HSP), [20]. The genetic basis for increased expression of anti-HSP 60/65 antibodies is considered [21]. Our observations indicate that the concentration of the anti-HSP $60 / 65$ in the serum of the experimental group is statistically significantly higher than in the control group and comparable to the comparison group, which suggests a common pathogenetic pathway of development of vascular lesions for atherosclerosis and diabetic macrovascular, in which both of the examined proteins are involved.

Immunohistochemical examination of vascular samples collected during internal carotid artery endarterectomy revealed the presence of heat shock protein HSP 60/65 in atherosclerotic vascular wall. Expression was observed after reaction with monoclonal mouse antibodies of antihHSP 60 mainly in macrophages of medial, vasa vasorum epithelial cells and endothelial vessel. Only in one case the presence of HSP in section of the vascular wall has not been proved. No heat shock protein expression in the endothelium of the internal carotid artery in some preparations shall be associated with the surgery technique, which resulted in the loss of endothelial layer of the vessel wall. Similar studies were conducted by $\mathrm{Kol}$ et al. [22], who demonstrated the presence of hHSP 60 in $89 \%$ of examined atherosclerotic plaques. The presence of HSP 60 on the surface of HUVEC was also identified by Pfister et al. [23]. However, according to information available to the authors, only this study showed a close, positive dependence of the presence of HSP 60/65 in the vessel wall on the concentration of anti-HSP 60/65 antibody in the serum of both the patients with diabetes complicated by peripheral macrovascular disease, and the patients with atherosclerotic vascular stenosis without this endocrinopathy. Therefore, the anti-HSP $60 / 65$ antibody concentration reflects the expression of the protein in the vascular wall. This study also proved the connection of the examined antibodies with the vascular endothelial dysfunction in the course of diabetic macrovascular disease. We used the von Willebrand factor as the marker of endothelial dysfunction. It is a glycoprotein produced by endothelial cells and platelets, involved in the process of adhesion and aggregation. The high concentration of von Willebrand factor in serum was found in patients with symptomatic peripheral macrovascular disease.

High concentrations of vWF remained in significant correlation with the anti - HSP 60/65 antibody concentration. Previously, a similar correlation was demonstrated in an experiment carried out on rabbits [23]. The role of immunoglobulin of anti - HSP 60/65 in atherogenesis was confirmed in another study conducted on animals, in which the anti-HSP 60 bodies isolated from the serum of patients with coronary artery disease were put intravenously into mice [24]. This experiment is the first report concerning the interaction of the anti-HSP 60/65 antibodies with vWF, as a marker of endothelial dysfunction in humans.

The concentration of anti-HSP 60/65 bodies can be affected by many factors, among them the permanent use of drugs. Statin therapy (simvastatin and atorvastatin) reduces the antibody concentration to anti-HSP 60/65 in the group of dyslipidemic patients [25]. This occurs most likely by lowering lipid levels, improving endothelial function, and the combination of anti-coagulants, anti-inflammatory and immunomodulatory activities of statins

This observation was confirmed by Shin et al. [26], in the parts relating to patients with coronary artery disease or after percutaneous coronary revascularization, but with the proviso that statin therapy was accompanied by rehabilitation. An interesting trend was observed in patients chronically treated with aspirin. Although the differences did not reach statistical significance, aspirin-treated patients were characterized by lower antibody-HSP60/65 concentation in the serum [26]. 
Perhaps this observation confirms the anti-inflammatory effect of treatment with low doses of aspirin. The effect of lower levels of antibodies was also detected in smokers [27]. This observation, especially surprising when confronted with the proven, highly proatherosclerotic effect of chronic nicotine addiction, is attempted to be explained by the smoke ingredients-caused damage of the cellular protection system created by HSP.

However, the factors discussed above cannot explain the observed tendency of the lower concentration of anti-HSP 60/65 in the serum in patients with type 2 diabetes mellitus complicated with peripheral macrovascular disease than in patients with atherosclerosis without disorders of carbohydrate metabolism. In both groups of patients the nicotine addiction was common. Patients with vascular complications of diabetes also received the oral antidiabetic drugs, and almost in half of the cases were treated with insulin (alone or in combination with oral agents), and thus the relationship between the observed tendency and the pharmacotherapy of diabetes cannot be excluded. The possibility of modulation of the expression of proteins HSP 60 in cardiac cells by insulin was suggested by Chen et al. [28]. The examined group was too small and heterogeneous (duration of diabetes, type of treatment) to allow a comprehensive assessment of the effect of the treatment with oral antidiabetic or insulin preparations on the changes in the concentration of anti-HSP $60 / 65$ antibodies.

\section{Conclusions}

1. Immunohistochemical study performed in patients with macrovascular diabetes proved the existance of the protein HSP $60 / 65$ in the vascular wall, indicating the accelerated development of the atherogenic processes in the experimental group.

2. The established correlation between the concentration of von Willebrand factor and the anti-HSP $60 / 65$ antibodies in the group of patients with macrovascular diabetes suggests their relationship with the vascular endothelial cells dysfunction and indicates their participation in the pathogenic pathway of macrovascular diabetes.

\section{References}

1. Carr ME (2001) Diabetes mellitus: a hypercoagulable state. J Diabetes Complications 15: 44-54

2. King H, Aubert RE, Herman WH (1998) Global burden of diabetes, 1995-2025: prevalence, numerical estimates, and projections. Diabetes Care 21: 14141431.

3. Garrido C, Gurbuxani S, Ravagnan L, Kroemer G (2001) Heat shock proteins: endogenous modulators of apoptotic cell death. Biochem Biophys Res Commun 286: 433-442.

4. Kirchhoff SR, Gupta S, Knowlton AA (2002) Cytosolic heat shock protein 60, apoptosis, and myocardial injury. Circulation 105: 2899-2904.

5. Wysocka M (2003) Tajemnice bialek szoku termicznego odsloniete. P Med 17: 30-31.

6. Perschinka H, Mayr M, Millonig G, Mayerl C, van der Zee R, et al. (2003) Crossreactive B-cell epitopes of microbial and human heat shock protein 60/65 in atherosclerosis. Arterioscler Thromb Vasc Biol 23: 1060-1065.

7. Cohen IR (1990) A heat shock protein, molecular mimicry and autoimmunity. Isr J Med Sci 26: 673-676.

8. Xu Q, Dietrich H, Steiner HJ, Gown AM, Schoel B, et al. (1992) Induction of arteriosclerosis in normocholesterolemic rabbits by immunization with heat shock protein 65. Arterioscler Thromb 12: 789-799.

9. Xu Q, Willeit J, Marosi M, Kleindienst R, Oberhollenzer F, et al. (1993)
Association of serum antibodies to heat-shock protein 65 with carotid atherosclerosis. Lancet 341: 255-259.

10. Gromadzka G, Zieliß̊,ska J, Ryglewicz D, Fiszer U, CzÅ,onkowska A (2001) Elevated levels of anti-heat shock protein antibodies in patients with cerebral ischemia. Cerebrovasc Dis 12: 235-239.

11. Mayr M, Kiechl S, Willeit J, Wick G, Xu Q (2000) Infections, immunity, and atherosclerosis: associations of antibodies to Chlamydia pneumoniae Helicobacter pylori, and cytomegalovirus with immune reactions to heat-shock protein 60 and carotid or femoral atherosclerosis. Circulation 102: 833-839.

12. Zhu J, Quyyumi AA, Rott D, Csako G, Wu H, et al. (2001) Antibodies to human heat-shock protein 60 are associated with the presence and severity of coronary artery disease: evidence for an autoimmune component of atherogenesis. Circulation 103: 1071-1075

13. Zhu J, Katz RJ, Quyyumi AA, Canos DA, Rott D, et al. (2004) Association of serum antibodies to heat-shock protein 65 with coronary calcification levels: suggestion of pathogen-triggered autoimmunity in early atherosclerosis. Circulation 109: 36-41.

14. Hoshida S, Nishino M, Tanouchi J, Kishimoto T, Yamada Y (2005) Acute Chlamydia pneumoniae infection with heat-shock-protein-60-related response in patients with acute coronary syndrome. Atherosclerosis 183: 109-112.

15. Rabczynski M, Fiodorenko-Dumas Z, Adamiec R, Paprocka-Borowicz M Dumas I (2012) Role of anti-HSP 60/65 antibodies in atherogenesis in patients with type 2 diabetes and lower limb ischemia. J Physiol Pharmacol 63: 691-696.

16. Xiao Q, Mandal K, Schett G, Mayr M, Wick G, et al. (2005) Association of serum-soluble heat shock protein 60 with carotid atherosclerosis: clinical significance determined in a follow-up study. Stroke 36: 2571-2576.

17. Mandal K, Jahangiri M, Xu Q (2004) Autoimmunity to heat shock proteins in atherosclerosis. Autoimmun Rev 3: 31-37.

18. Maron R, Sukhova G, Faria AM, Hoffmann E, Mach F, et al. (2002) Mucosal administration of heat shock protein-65 decreases atherosclerosis and inflammation in aortic arch of low-density lipoprotein receptor-deficient mice. Circulation 106: 1708-1715

19. Mandal K, Foteinos G, Jahangiri M, Xu Q (2005) Role of antiheat shock protein 60 autoantibodies in atherosclerosis. Lupus 14: 742-746.

20. Xu Q, Schett G, Perschinka H, Mayr M, Egger G, et al. (2000) Serum soluble heat shock protein 60 is elevated in subjects with atherosclerosis in a general population. Circulation 102: 14-20.

21. Veres A, Prohászka Z, Kilpinen S, Singh M, Füst G, et al. (2002) The promoter polymorphism of the IL-6 gene is associated with levels of antibodies to $60-\mathrm{kDa}$ heat-shock proteins. Immunogenetics 53: 851-856.

22. Kol A, Sukhova GK, Lichtman AH, Libby P (1998) Chlamydial heat shock protein 60 localizes in human atheroma and regulates macrophage tumor necrosis factor-alpha and matrix metalloproteinase expression. Circulation 98 300-307.

23. Pfister G, Stroh CM, Perschinka H, Kind M, Knoflach M, et al. (2005) Detection of HSP60 on the membrane surface of stressed human endothelial cells by atomic force and confocal microscopy. J Cell Sci 118: 1587-1594.

24. Anderson R, Dart AM, Starr J, Shaw J, Chin-Dusting JP (2004) Plasma C-reactive protein, but not protein S, VCAM-1, von Willebrand factor or $\mathrm{P}$-selectin, is associated with endothelium dysfunction in coronary artery disease. Atherosclerosis 172: 345-351.

25. Ghayour-Mobarhan M, Lamb DJ, Vaidya N, Livingstone C, Wang T, et al. (2005) Heat shock protein antibody titers are reduced by statin therapy in dyslipidemic subjects: a pilot study. Angiology 56: 61-68.

26. Shin YO, Bae JS, Lee JB, Kim JK, Kim YJ, et al. (2006) Effect of cardiac rehabilitation and statin treatment on anti-HSP antibody titers in patients with coronary artery disease after percutaneous coronary intervention. Int Heart J 47: 671-682.

27. Frostegård J, Lemne C, Andersson B, van der Zee R, Kiessling R, et al. (1997) Association of serum antibodies to heat-shock protein 65 with borderline hypertension. Hypertension 29: 40-44.

28. Chen HS, Shan YX, Yang TL, Lin HD, Chen JW, et al. (2005) Insulin deficiency downregulated heat shock protein 60 and IGF-1 receptor signaling in diabetic myocardium. Diabetes 54: 175-181. 